\title{
ACUTE DRUG-ALLERGIC TUBULOINTERSTITIAL NEPHRITIS
}

\author{
Daniela Rădulescu \\ University of Medicine and Pharmacy "Carol Davila” Bucharest \\ Emergency Clinical Hospital "St. John”
}

\begin{abstract}
Acute drug-allergic tubulointerstitial nephrites are increasingly common conditions in current practice due to increased patient access to a variety of drugs. The clinical-biological panel associates acute renal injury with hypersensitivity phenomena. Considered classically reversible after the cessation of the incriminated drug, drug-allergic tubulointerstitial nephrites have changed their evolutionary characteristics in recent decades, even under treatment. This article presents the clinical-biological, therapeutic and evolutionary characteristics of drug-allergic tubulointerstitial nephrites.
\end{abstract}

Keywords: acute tubulointerstitial nephritis, drugs, hypersensitivity, tubulointerstitial inflammation, acute renal injury

\section{Rezumat}

Nefritele tubulointerstiţiale alergic medicamentoase sunt afecţiuni tot mai frecvente în practica curentă ca urmare a accesului crescut al pacienţilor la o varietate de medicamente. Tabloul clinico-biologic asociază injurie renală acută cu fenomene de hipersensibilitate. Considerate clasic reversibile după sistarea medicamentului incriminat, nefritele tubulointerstiţiale alergic medicamentoase şi-au modificat în ultimele decenii caracterele evolutive, chiar sub tratament. Articolul de faţă prezintă caracteristicile clinico-biologice, terapeutice şi evolutive ale nefritelor tubulointerstiţiale alergic medicamentoase.

Cuvinte cheie: nefrită tubulointerstiţială acută, medicamente, hipersensibilitate, inflamaţie tubulointerstiţială, injurie renală acută 


\section{INTERNAL}

\section{General Reviews}

\section{Introduction}

The supply of drugs for various ailments, from common diseases such as respiratory viruses to advanced neoplasms, has increased considerably in recent decades.

The kidney, a highly vascularized organ with a urine concentration system ${ }^{(1,2)}$, is highly susceptible to a myriad of drug-induced side effects $^{(3,4)}$. If some of these side effects may be considered iatrogenic (e.g. acute renal injury to gentamicin) or "accidental" (e.g. acute renal injury after contrast agent absolutely necessary to be used), being dose-dependent, acute drug-allergic tubulointerstitial nephropathies (ADATIN) are part of the renal side effects impossible to prevent ${ }^{(5)}$. Over 150 drugs are reported to induce ADATIN, but the most commonly responsible are the therapeutic classes commonly recommended in current practice in all specialties: antibiotics, nonsteroidal anti-inflammatory drugs (NSAIDs) and proton pump inhibitors ${ }^{(6)}$. The classic clinical-biological panel of ADATIN is characterized by the association of acute renal injury (ARI) with allergic phenomena a few days after the administration of a drug. Unfortunately, in current practice, the typical clinical panel is rarely present, often these conditions being labelled as ARI of unknown cause.

This article presents the general clinicalbiological, therapeutic and evolutionary characteristics of ADATIN, as well as the specific features of some ADATIN subject to the most frequently responsible drugs.

\section{Epidemiology, etiology, risk factors}

Acute tubulointestinal nephrites (ATIN) are the third leading cause of acute renal injury after prerenal azotemia and acute tubular necrosis $^{(7,8)}$. The exact frequency of ATIN is probably underestimated, as the definite diagnosis is established by renal biopsy ${ }^{(9,10)}$ which is not performed, for various reasons, in all cases ${ }^{(11)}$.

From the reports of different national renal biopsy registries, the prevalence of bioptic detection of ATIN varies between 1 and $10 \%$ of all biopsies performed for various indications and between 6.5 and $35 \%$ of biopsied cases to elucidate the cause of acute renal injury ${ }^{(12,13)}$.

From an etiological point of view, ATIN can be divided into medicinal, infectious, secondary to systemic and idiopathic diseases ${ }^{(14)}$; over $70 \%$ of cases are attributed to drugs ${ }^{(10,12,15,16)}$.

The frequency of ADATIN is higher in developed countries due to increased access to a wide range of drugs ${ }^{(10)}$. Over 150 drugs have been reported in the literature as potential inducers of ADATIN (table 1). The list is constantly growing through the introduction in recent decades of various therapies for conditions traditionally 


\begin{tabular}{|c|c|}
\hline Antibiotics & $\begin{array}{l}\text { B-lactamines (Penicillins, Cephalosporins) } \\
\text { Fluoroquinolones (ciprofloxacin) } \\
\text { Sulfamides (biseptol, nitrofurantoin) } \\
\text { Rifampicin } \\
\text { Macrolides (clarithromycin, telethromycin) } \\
\text { Vancomycin, etc. }\end{array}$ \\
\hline NSAIDs & $\begin{array}{l}\text { All, including aspirin, including selective COX }-2 \\
\text { inhibitors }\end{array}$ \\
\hline $\begin{array}{l}\text { Gastric antisecretory } \\
\text { drugs }\end{array}$ & $\begin{array}{l}\text { Proton pump inhibitors: omeprazole, lansoprazole, } \\
\text { pantoprazole, esomeprazole } \\
\text { H2 blockers: cimetidine, famotidine, ranitidine }\end{array}$ \\
\hline 5-aminosalicylates & Sulfasalazine, mesalazine \\
\hline Diuretics & Furosemide, bumetanide, hydrochlorothiazide \\
\hline Immunoactive agents & $\begin{array}{l}\text { PD-1 / PD-L1 inhibitors (nivolumab, pembrolizumab, } \\
\text { cemiplimab, atezolizumab, etc.) } \\
\text { CTLS-4 inhibitors (ipilimumab, tremelimumab) }\end{array}$ \\
\hline $\begin{array}{l}\text { Angiogenesis } \\
\text { inhibitors }\end{array}$ & Tyrosine kinase inhibitors (sorafenib, sunitanib) \\
\hline Various & $\begin{array}{l}\text { Antivirals (Acyclovir, Indinavir); Anticonvulsants } \\
\text { (phenytoin, phenobarbital, carbamazepine), } \\
\text { allopurinol, amlodipine, captopril }\end{array}$ \\
\hline
\end{tabular}

Table 1. Drugs that may induce acute drug-allergic tubulointerstitial nephritis

Key: PD-1, programmed cell death protein-1; PD-L1, programmed death ligand 1; CTLA-4, cytotoxic T-lymphocyte antigen-4 


\section{INTERNAL}

\section{General Reviews}

considered without therapeutic resources, such as immunomodulators (immune checkpoint inhibitors) used successfully in the therapy of advanced neoplasms. However, despite the diversification of drugs that can cause ADATIN, the top spots, in terms of frequency, are taken by the same classes (obviously enriched with new molecules) as 40 years ago: antibiotics and NSAIDs ${ }^{(17)}$. In addition, more and more cases of ATIN after proton pump inhibitors are reported $^{(15,18,19)}$. With considerable frequency, compared to the $1980 \mathrm{~s}^{(20)}$, there are cases of ATIN after 5-aminosalicylates and new chemotherapeutic agents ${ }^{(10,21-23)}$.

With the exception of either doctor prescribed drugs or over-the-counter drugs, we cannot mention the existence of risk factors for ADATIN because the mechanism of this pathology is allergic, therefore impossible to predict. A higher frequency of ADATIN is reported in the literature in elder patients, but this does not appear to be related to age-specific immune changes per se, but to the increased number of drugs that the elderly take ${ }^{(24)}$.

\section{Pathogenesis}

The pathogenic mechanism of ADATIN is of the allergic type, most often involving cellular immunity ${ }^{(12,14,25)}$. Drugs can act through different mechanisms ${ }^{(5,14,26)}$ :
- in the form of hapten, binding to a protein component of the tubular basement membrane (TBM);

- by resemblance to a normal TBM antigen or interstice, inducing a crossimmune response;

- in the form of an antigen "planted" at the level of TBM or of the interstice with the appearance of antibodies against it;

- causes the formation of circulating antibodies, and the circulating immune complexes are subsequently deposited in the interstice.

\section{Clinical and paraclinical panel}

ATIN is characterized, from an anatomopathological point of view, by diffuse or focal interstitial inflammatory infiltrate ${ }^{(14,27)}$, consisting mainly of $\mathrm{T}$ lymphocytes, monocytes, macrophages, sometimes eosinophils and even neutrophils. Sometimes, it looks like granulomatous infiltrate, containing giant cells. The clinical and biological manifestations of ATIN are the result of the extension of the inflammatory infiltrate and of the interstitial oedema to the adjacent tubules that present inflammatory lesions (appearance of tubulitis or even of necrosis with variable extension). Most often, no glomerular lesions appear, and if they do occur (most often in ATIN after NSAIDs), they 
are usually in the form of a glomerular nephropathy with minimal lesions and are not seen in light microscopy ${ }^{(14)}$.

The classic clinical panel of ADATIN was first described after methicillin administration ${ }^{(5,28)}$ and consists in the appearance, a few days after the administration of a drug, of oliguric ARI associated with the classical triad: fever, maculopapular rash and eosinophilia. Other nonspecific manifestations may be associated, such as chills, arthralgias, myalgia, dull low back pain, nausea, physical asthenia, general malaise. Oedema and high blood pressure (HBP) are absent. Urine examination shows tubulointerstitial changes: low urine density; reduced, tubular type proteinuria with low molecular weight proteins; microscopic hematuria, but with isomorphic red blood cells and usually without blood cylinders; significant leukocyturia with leukocyte cylinders and, specifically, increased eosonophiluria. Manifestations do not depend on the dose and recur if the same drug or even a related drug is administered ${ }^{(29,30)}$.

Currently, the classic clinical panel is rarely present. The interval between drug administration and the onset of symptoms can range from 1 day (typically for rifampicin, especially when resuming treatment) to a few days (typically for methicillin, amoxicillin), a few weeks (immune checkpoint inhibitors) or even months (for NSAIDs or proton pump inhibitors) which makes it difficult to establish the diagnosis ${ }^{(25,31-33)}$.

Both the classic triad fever-rash-eosinophilia and some of each of its components are quite rare today. A meta-analysis frequently cited in the literature ${ }^{(34)}$ shows that, out of 128 patients diagnosed with ATIN, of whom $70 \%$ had ADATIN, the rash was present in only 14.8 $\%$, fever in $27.3 \%$, eosinophilia in $23.3 \%$, and the entire triad in only $10 \%$ of patients. There are also cases that show no sign of hypersensitivity ${ }^{(35)}$, many being labelled as ARI of unknown cause.

Regarding urinary manifestations, here too the profile of alterations can often be nonspecific for ADATIN. Thus, in about $50 \%$ of the cases, ARI are preserved with diuresis; hematuria is present in less than half the patients ${ }^{(36)}$. Changes in fractional urinary excretion of sodium and urea can be both prerenal ARI and intrinsic ARI ${ }^{(14,37)}$. Eosinophiluria (over $1 \%$ of leukocytes in the urine), considered highly suggestive, is not routinely sought because it requires special staining that is not widely available. Eosinophilia can also occur in ARI from other causes: thromboembolic kidney disease, acute tubular necrosis, etc. ${ }^{(38,39)}$. Proteinuria may be of nephrotic rank, especially in cases of ADATIN induced by NSAIDs ${ }^{(30)}$.

With the exception of renal biopsy, there are no paraclinical investigations that would provide additional benefits for a positive diagnosis of ADATIN. Ultrasound is useful only to rule out an obstructive ARI, the kidneys often having a normal appearance or being slightly enlarged due to interstitial oedema $^{(8,40)}$. Scintigraphy with Gallium-67 shows diffuse hyper-capture in the kidneys, but is nonspecific for ATIN, as similar changes may also occur in other forms of ARI, glomerular disorders, etc. ${ }^{(14,41-43)}$.

Although it provides a definite diagnosis, kidney biopsy is often not routinely performed; in the face of high clinical suspicion, ARI resolution, and clinicalbiological changes after cessation of the offending drug, biopsy is often no longer necessary. However, in cases where there are several potentially responsible drugs, when the ARI does not remit after stopping the drug or after initiating corticosteroid treatment, biopsy is recommended ${ }^{(30)}$. Biopsy not only 


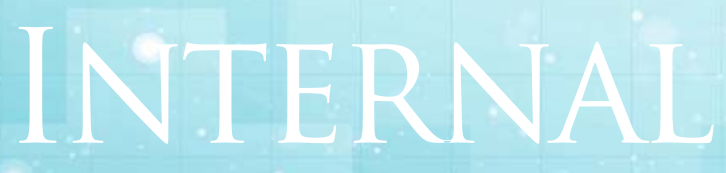

General Reviews

provides the etiological diagnosis of ARI, but is particularly useful for detecting interstitial fibrosis and its extension, situations that point to the evolution towards chronicity and the uselessness of continuing corticosteroid treatment ${ }^{(30)}$.

\section{Evolution and prognosis}

Traditionally, ADATINs were considered completely reversible after cessation of the etiological agent combined or not with corticosteroid treatment ${ }^{(30,34)}$. Given the diversification of classes of potentially nephrotoxic drugs and polypragmasia, there is currently evidence of the potential for chronicity of these conditions. Complete recovery of renal function after ADATIN is cited in about $60-65 \%$ of patients, while incomplete recovery occurs in 10-20\% of patients and lack of recovery with chronic dialysis dependence in $5-10 \%{ }^{(12,44)}$. The risk of chronicity is higher in situations with severe ARI requiring dialysis, long-term ARI, over 3 weeks, or secondary NSAID ARI ${ }^{(30,45)}$. Chronic biopsy markers consist of the presence and extent of interstitial fibrosis, the presence of tubular atrophy ${ }^{(30,46)}$.

\section{Treatment principles}

Stopping treatment with the responsible drug is the main measure and sometimes sufficient for the recovery of renal function ${ }^{(12)}$. In patients who have treatment regimens with several drugs potentially responsible for ADATIN, some authors ${ }^{(30)}$ recommend their sequential discontinuation and renal biopsy as soon as possible, in the absence of contraindications; in the face of a severe form of ARI, which requires dialysis, it is preferable to discontinue all risk drugs ${ }^{(30)}$. Lack of recovery of renal function within a few days from discontinuation of the drug requires treatment with corticosteroids. Usually short courses of $1 \mathrm{mg} / \mathrm{kg} / \mathrm{day}$ of prednisone are used for 1-2 weeks until the signs of recovery of renal function appear, then the doses are progressively decreased in a few weeks. The use of intravenous methylprednisolone pulse therapy $500 \mathrm{mg}-1 \mathrm{~g} /$ day intravenously, 3 consecutive days before oral prednisone therapy $1 \mathrm{mg} / \mathrm{kg} /$ day may be necessary in severe cases of ARI requiring dialysis.

Decisions to initiate corticosteroid therapy and biopsy should be made quickly within a few days of severe ARIs due to the risk of chronicity ${ }^{(12,44)}$. In case of lack of response to corticosteroid therapy initiated without histological confirmation, renal biopsy is essential; it provides information on either another etiology of ARI or the onset of tubulointerstitial fibrosis.

There are reports in the literature on the use of other immunosuppressive treatments (mycophenolate mofetil, cyclosporine, 
cyclophosphamide) in ADATINs that do not respond to corticosteroids and in which biopsy shows acute inflammatory infiltrate, but these include a small number of patients and experience is limited ${ }^{(47)}$. These immunosuppressants are especially useful in patients with NSAIDs-induced ADATINs who do not respond to regular corticosteroids or who require prolonged course of corticosteroids and who experience specific side effects.

\section{Particular forms of adatin}

\section{ATIN to proton pump inhibitors}

Proton pump inhibitors (PPIs) are frequently recommended in long-term treatment regimens by physicians of various specialties, often to counteract the possible gastric side effects of other drugs, but are also selfadministered over-the-counter by patients ${ }^{(48)}$. They are drugs that generally have few side effects $^{(48)}$. ATINs occur in less than $1 \%$ of patients using PPIs, but due to the fact that they are the most widely used class of drugs in current practice, they occupy one of the top 3 places among the most common causes of ADATIN. The first drug reported as an etiological agent in the literature was omeprazole ${ }^{(49)}$, but later, secondary cases to other PPIs were published: lanzoprazole ${ }^{(50)}$, esomeprazole ${ }^{(51)}$, rabeprazole(52), pantoprazole ${ }^{(53)}$.

The clinical panel of ADATIN in PPI is often atypical: ARI, often unaccompanied by systemic hypersensitivity phenomena, develops subacutely or slowly over a period of time that can vary between a few days and a few months after the administration of $P P^{(54,55)}$. Higher frequency in the elderly ${ }^{(15,17,30,56)}$, increased risk of incomplete recovery of renal function ${ }^{(57)}$ and progression to chronicity ${ }^{(54)}$ even with prompt corticosteroid treatment instituted after biopsy confirmation, are cited. Eosinophilia is quite common ${ }^{(58)}$, but the other specific manifestations of ATIN are inconsistent ${ }^{(59)}$, and many cases are therefore classified as ARI of unknown cause until the biopsy result is obtained. In some non-Caucasian races, a genetic predisposition for ADATIN to PPI has been described ${ }^{(60)}$. Because PPIs are metabolized in the hepatic cytochrome P450 enzyme system, patients with genetic polymorphism of CYT P450 appear to be at risk for ADATIN due to the accumulation of PPIs and/or their metabolites in the kidneys where they elicit an immune-mediated interstitial inflammatory response ${ }^{(19)}$.

\section{ATIN to rifampicin}

ATIN to rifampicin, a basic component of antituberculosis treatment regimens, usually occur upon reintroduction/resumption of treatment, and is less commonly reported during continuous treatment ${ }^{(14,29,30)}$. The clinical panel is characterized by severe oliguric $A R I$, often requiring dialysis therapy ${ }^{(61)}$, but with good recovery under treatment ${ }^{(62)}$. ARI associates fever and general digestive phenomena (nausea, vomiting, diarrhoea, abdominal cramps) and less often typical signs of hypersensitivity (skin rash, eosinophilia) $^{(14,62)}$. Haemolytic anaemia, thrombocytopenia and acute hepatitis are cited as characteristic features, associated with acute renal injury ${ }^{(14)}$. Antirifampicin antibodies are detected in the serum that can be deposited at glomerulus, interstitium or intrarenal vessels level ${ }^{(63)}$; therefore, ARI by ATIN to rifampicin should be differentiated by biopsy from other types of ARIs induced by rifampicin, by means of glomerulonephritis or acute tubular necrosis $^{(29,64)}$. In most cases, the signs of interstitial involvement are sufficient to 


\section{INTERNAL}

\section{General Reviews}

establish the diagnosis of ADATIN; biopsy is performed in cases of significant proteinuria or if renal function does not recover after rifampicin discontinuation ${ }^{(61)}$. From an anatomopathological point of view, ATIN to rifampicin typically associates, in addition to the interstitial inflammatory infiltrate, important tubular lesions, sometimes with clinical resonance ${ }^{(65)}$. Antirifampicin antibodies are not present in the kidneys in case of ATIN during continuous treatment with rifampicin, which shows that, in these cases, tubulointerstitial impairment is produced by cellular immune mechanism ${ }^{(14)}$.

\section{ATIN to nonsteroidal anti-inflammatory drugs}

ATIN after nonsteroidal anti-inflammatory drugs (NSAIDs) may occur as an adverse effect of any class of NSAIDs, including selective COX2 inhibitors, as well as topically administered preparations ${ }^{(30,66-69)}$. Interstitial accumulation of arachidonic acid metabolism products results in immune-mediated stimulation of $\mathrm{T}$ lymphocytes, which explains both the predominant inflammatory infiltrate of $T$ lymphocytes and concomitant glomerular impairment ${ }^{(70)}$; granulomatous infiltrates are described ${ }^{(71)}$, as well.

ATIns in NSAIDs have some features that may make it difficult to diagnose, in the case of ARIs in a polymedicated patient, and may help, on the other hand, to differentiate them from other forms of NSAIDs-induced ARIs, especially by hemodynamic mechanism ${ }^{(14,70)}$. These characteristics refer primarily to the possibility of an ARI occurring after several months of NSAID use ${ }^{(14,72)}$; recurrence of resumption of treatment is also reported ${ }^{(73,74)}$. In most cases, ATIN to NSAIDs associate a nephrotic syndrome via glomerulopathy with minimal lesions or membranous glomerulopathy ${ }^{(30,66,75,76)}$. The clinical picture rarely includes manifestations of hypersensitivity, usually isolated, and nephrotic oedema is quasi-present. In many cases, ARI resolve spontaneously after discontinuation of NSAIDs, usually slowly, within a few weeks ${ }^{(14,30,77)}$; however, at least $25 \%$ of cases that recover incompletely are described. Corticosteroid treatment is not as effective as in other ADATINs.

\section{Conclusions}

Acute drug tubulointerstitial nephropathies are a common cause of acute renal injury. Given the immunoallergic nature of these conditions, there are no prophylaxis measures except to avoid polypragmasia. Clinical suspicion is particularly important for diagnosis, as clinical manifestations are often incomplete and atypical. Renal biopsy provides a definite diagnosis. Discontinuation of the drug and short-term treatment with corticosteroids are the necessary measures to be applied promptly, because, although 
considered classically reversible, currently acute drug tubulointerstitial nephropathies are recorded to have a considerable risk of chronicity.

\section{References}

1. Raghavan R, Shawar S. Mechanisms of DrugInduced Interstitial Nephritis. Adv Chronic Kidney Dis. 2017; 24(2): 64-71.

2. Perazella MA. Renal Vulnerability to Drug Toxicity. CJASN. 2009; 4(7): 1275-1283.

3. Perazella MA. Drug-induced nephropathy: an update. Expert Opin Drug Saf. 2005; 4(4): 689-706.

4. Markowitz GS, Perazella MA. Drug-induced renal failure: a focus on tubulointerstitial disease. Clin Chim Acta. 2005; 351(1-2): 31-47.

5. Rossert J. Drug-induced acute interstitial nephritis. Kidney Int. 2001; 60(2): 804-817.

6. Perazella MA, Markowitz GS: Drug-induced acute interstitial nephritis. Nat Rev Nephrol. 2010; 6(8): 461470.

7. Wilson DM, Turner DR, Cameron JS, Ogg CS, Brown $C B$, Chantler $C$. Value of renal biopsy in acute intrinsic renal failure. BrMed J. 1976; 2(6033): 459-461.

8. Perazella MA. Diagnosing drug-induced AIN in the hospitalized patient: a challenge for the clinician. Clin Nephrol. 2014; 81(6): 381-388.

9. Nussbaum EZ, Perazella MA. Diagnosing acute interstitial nephritis: considerations for clinicians. Clin KidneyJ. 2019; 12(6): 808-813.

10. Nast CC. Medication-Induced Interstitial Nephritis in the 21st Century. Adv Chronic Kidney Dis. 2017; 24(2): 72-79.

11. Stillman IE Lima EQ Burdmann EA. Renal biopsies in acute kidney injury: who are we missing? Clin J Am Soc Nephrol. 2008; 3(3): 647-648.

12. Raghavan R, Eknoyan G. Acute interstitial nephritis a reappraisal and update. Clin Nephrol. 2014; 82(3): 149162.

13. Farrington $K$, Levison DA, Greenwood RN, Cattell WR, Baker LR. Renal biopsy in patients with unexplained renal impairment and normal kidney size. Q J Med. 1989; 70(263): 221-233.

14. RossertJA, Fischer EA. Acute Interstitial Nephritis. În: Feehally J, Floege J, Tonelli M, Johnson RJ (editori): Comprehensive Clinical Nephrology, ediţia a 6-a, Elsevier. 2019; pag. 729-737.

15. Muriithi AK, Leung N, Valeri AM, Cornell LD, Sethi S, Fidler ME, Nasr SH. Biopsy-proven acute interstitial nephritis, 1993-2011: a case series. Am J Kidney Dis. 2014; 64(4): 558-566.

16. Moledina DG, Perazella MA. Drug-induced acute interstitial nephritis. Clin J Am Soc Nephrol. 2017; 12(12):
2046-2049.

17. Praga M, Sevillano A, Auñón P, González E. Changes in the aetiology, clinical presentation and management of acute interstitial nephritis, an increasingly common cause of acute kidney injury. Nephrol Dial Transplant. 2015; 30(9): 1472-1479.

18. Blank ML, Parkin L, Paul C, Herbison P. A nationwide nested case-control study indicates an increased risk of acute interstitial nephritis with proton pump inhibitor use. Kidney Int. 2014; 86(4): 837-844.

19. Brewster UC, Perazella MA. Proton pump inhibitors and the kidney: critical review. Clin Nephrol. 2007; 68(2): 65-72.

20. Pusey CD, Saltissi D, Bloodworth L, Rainford DJ, Christie JL. Drug associated acute interstitial nephritis: clinical and pathological features and the response to high dose steroid therapy. Q J Med. 1983; 52(206): 194211.

21. Nussbaum EZ, Perazella MA. Update on the nephrotoxicity of novel anticancer agents. Clin Nephrol 2018; 89(3): 149-165.

22. Perazella MA, Shirali AC. Nephrotoxicity of cancer immunotherapies: past, present and future. J Am Soc Nephrol; 29(8): 2039-2052.

23. Airy M, Raghavan R, Truong LD, Eknoyan G. Tubulointerstitial nephritis and cancer chemotherapy: update on a neglected clinical entity. Nephrol Dial Transplant. 2013; 28(10): 2502-2509.

24. Muriithi AK, Leung N, Valeri AM, Cornell LD, Sethi S, Fidler ME, Nasr SH. Clinical characteristics, causes and outcomes of acute interstitial nephritis in the elderly. Kidney Int. 2015; 87(2): 458-464.

25. Neilson EG. Pathogenesis and therapy of interstitial nephritis. Kidney Int. 1989; 35(5): 1257-1270.

26. Krishnan N, Perazella MA. Drug-induced acute interstitial nephritis: pathology, pathogenesis, and treatment. Iran J Kidney Dis. 2015; 9(1): 3-13.

27. Galpin JE, ShinabergerJH, Stanley TM, Blumenkrantz MJ, Bayer AS, Friedman GS, Montgomerie JZ, Guze LB, Coburn JW, Glassock RJ. Acute interstitial nephritis due to methicillin. AmJ Med. 1978; 65(5): 756-765.

28. Baldwin DS, Levine BB, McCluskey RT, Gallo GR. Renal failure and interstitial nephritis due to penicillin and methicillin. N EnglJ Med. 1968; 279(23): 1245-1252.

29. Schubert C, Bates WD, Moosa MR. Acute tubulointerstitial nephritis related to antituberculous drug therapy. Clin Nephrol. 2010; 73(6): 413-.

30. Praga M, Appel GB. Clinical manifestations and diagnosis of acute interstitial nephritis. UPTODATE 2018. Disponibil la: https://www.uptodate.com, accesat aprilie 2020.

31. Ten RM, Torres VE, Milliner DS, Schwab TR, Holley KE, Gleich GJ. Acute interstitial nephritis: immunologic and clinical aspects. Mayo Clin Proc. 1988; 63(9): 921-930. 


\section{INTERNAL}

\section{ME}

General Reviews

32. Clive DM, StoffJS. Renal syndromes associated with nonsteroidal antiinflammatory drugs. N EnglJ Med. 1984; 310(9): 563-572.

33. Belliere J, Meyer N, Mazieres J, Ollier S, Boulinguez S, Delas A, Ribes D, Faguer S. Acute interstitial nephritis related to immune checkpoint inhibitors. $\mathrm{Br} J$ Cancer. 2016; 115(12): 1457-146.

34. Baker RJ, Pusey CD. The changing profile of acute tubulointerstitial nephritis. Nephrol Dial Transplant. 2004; 19(1): 8-11.

35. Kodner CM, Kudrimoti A. Diagnosis and management of acute interstitial nephritis. Am Fam Physician. 2003; 67(12): 2527-2534.

36. Praga M, González E. Acute interstitial nephritis. Kidney Int. 2010; 77(11): 956-961.

37. Saha H, Mustonen J, Helin H, Pasternack A. Limited value of the fractional excretion of sodium test in the diagnosis of acute renal failure. Nephrol Dial Transplant. 1987; 2(2): 79-82.

38. Muriithi AK, Nasr SH, Leung N. Utility of urine eosinophils in the diagnosis of acute interstitial nephritis. Clin J Am Soc Nephrol. 2013; 8(11):1857-1862.

39. Espejo B, Herrero JC, Torres A, Martínez A, Gutiérrez E, Morales E, González E, Bueno B, Valentín MO, Praga M. Immunoallergic interstitial nephritis vs. cholesterol atheroembolism. Differentiating characteristics. Nefrologia. 2003; 23(2): 125-130.

40. Hiraoka M Hori C Tsuchida S Tsukahara H Sudo M Ultrasonographic findings of acute tubulointerstitial nephritis. Am J Nephrol. 1996; 16(2): 154-158.

41. Linton $A L$, Richmond JM, Clark WF, et al. Gallium67 scintigraphy in the diagnosis of acute renal disease. Clin Nephrol. 1985; 24(2): 84-87.

42. Koselj M Kveder R Bren AF Rott T Acute renal failure in patients with drug-induced acute interstitial nephritis. Ren Fail. 1993; 15(1): 69-72.

43. Graham F, Lord M, Froment $D$, Cardinal $H$, Bollée $G$. The use of gallium-67 scintigraphy in the diagnosis of acute interstitial nephritis. Clin Kidney J. 2016; 9(1): 76-81.

44. Eknoyan $G$ Raghavan $R$ Acute tubulointerstitial nephritis. În: Coffman T, Falk R, Molitoris B, Neilson E, Schrier RW (editori). Schrier's Diseases of the Kidney.
Ediţia a 9-a. Philadelphia, PA: Lippincott, Williams\&Wilkins. 2013; pag.994-1017.

45. Schwarz A, Krause PH, KunzendorfU, Keller F, Distler A. The outcome of acute interstitial nephritis: risk factors for the transition from acute to chronic interstitial nephritis. Clin Nephrol. 2000; 54(3): 179-190.

46. Fernandez-Juarez G, Perez JV, Caravaca-Fontán F, Quintana L, Shabaka A, Rodriguez E, Gadola L, de Lorenzo A, Cobo MA, Oliet A, Sierra M, Cobelo C, Iglesias E, Blasco M, Galeano C, Cordon A, Oliva J, Praga M, Spanish Group for the Study of Glomerular Diseases (GLOSEN). Duration of treatment with corticosteroids and recovery of kidney function in acute interstitial nephritis. Clin J Am Soc Nephrol. 2018; 13(12): 1851-1858.

47. Preddie DC, Markowitz GS, Radhakrishnan J, Nickolas TL, D'Agati VD, SchwimmerJA, Gardenswartz M, Rosen R, Appel GB. Mycophenolate mofetil for the treatment of interstitial nephritis. Clin J Am Soc Nephrol. 2006; 1(4): 718-722.

48. Forgacs I, Loganayagam A. Overprescribing proton pump inhibitors. BMJ. 2008; 336(7634): 2-3.

49. Ruffenach SJ, Siskind MS, Lien YH. Acute interstitial nephritis due to omeprazole. Am J Med. 1992; 93(4): 472473.

50. Torpey N, Barker T, Ross C. Drug-induced tubulointerstitial nephritis secondary to proton pump inhibitors: experience from a single UK renal unit. Nephrol Dial Transplant. 2004; 19(6): 1441-1446.

51. Geevasinga N, Kairaitis L, Rangan GK, Coleman PL. Acute interstitial nephritis secondary to esomeprazole. Med J Aust. 2005; 182(5): 235-236.

52. Geevasinga N, Coleman PL, Roger SD. Rabeprazoleinduced acute interstitial nephritis. Nephrology (Carlton). 2005; 10(1): 7-9.

53. Klassen S, Krepinsky JC, Prebtani AP. Pantoprazoleinduced acute interstitial nephritis. CMAJ. 2013; 185(1): 56-59.

54. Moledina DG, Perazella MA. PPIs and kidney disease: from AIN to CKD. J Nephrol. 2016; 29(5): 611-616.

55. Sampathkumar K, Ramalingam R, Prabakar A, Abraham A. Acute interstitial nephritis due to proton 
pump inhibitors. Indian J Nephrol. 2013; 23(4): 304-307. 56. Antoniou T, Macdonald EM, Hollands $S$, Gomes $T$, Mamdani MM, Garg AX, Paterson M, Juurlink DN. Proton pump inhibitors and the risk of acute kidney injury in older patients: a population-based cohort study. CMAJO. 2015; 3(2): E166-E171.

57. Simpson IJ, Marshall MR, Pilmore $H$, Manley $P$, Williams $L$, Thein $H$, Voss $D$. Proton pump inhibitors and acute interstitial nephritis: report and analysis of 15 cases. Nephrology (Carlton). 2006; 11(5): 381-385.

58. Geevasinga N, Coleman PL, Webster AC, Roger SD. Proton pump inhibitors and acute interstitial nephritis. Clin Gastroenterol Hepatol. 2006; 4(5): 597-604.

59. Morschel CF, Mafra D, Eduardo JCC. The relationship between proton pump inhibitors and renal disease. J Bras Nefrol. 2018; 40(3): 301-306.

60. Ball S, Cook T, Hulme B, Palmer A, Taube D. The diagnosis and racial origin of 394 patients undergoing renal biopsy: An association between Indian race and interstitial nephritis. Nephrol Dial Transplant. 1997; 12(1): 71-77.

61. Manika K, Tasiopoulou K, Vlogiaris L, Lada M, Papaemmanouil S, Zarogoulidis K, Kioumis I. Rifampicinassociated acute renal failure and hemolysis: a rather uncommon but severe complication. Ren Fail. 2013; 35(8): 1179-1181.

62. De Vriese AS, Robbrecht $D L$, Vanholder $R C$, Vogelaers DP, Lameire NH. Rifampicin-associated acute renal failure: pathophysiologic, immunologic, and clinical features. Am J Kidney Dis. 1998; 31(1): 108-115. 63. Muthukumar T, Jayakumar M, Fernando EM, Muthusethupathi MA. Acute renal failure due to rifampicin: a study of 25 patients. Am J kidney Dis. 2002; 14(4): 690-696.

64. Ortiz A, Barat A, Oliva H. Acute kidney failure induced by rifampicin. Nefrologia. 2001; 21(1): 92-94.

65. Min HK, Kim EO, Lee SJ, Chang YK, Suh KS, Yang CW, Kim SY, Hwang HS. Rifampin-associated tubulointersititial nephritis and Fanconi syndrome presenting as hypokalemic paralysis. BMC Nephrol. 2013; 14:13.

66. Alper $A B$ Jr, Meleg-Smith S, Krane NK. Nephrotic syndrome and interstitial nephritis associated with celecoxib. AmJ Kidney Dis. 2002; 40(5): 1086-1090.

67. Andrews PA, Sampson SA. Topical non-steroidal drugs are systemically absorbed and may cause renal disease. Nephrol Dial Transplant. 1999; 14(1): 187-189.

68. Krummel T, Dimitrov $Y$, Moulin B, Hannedouche $T$. Drug points: Acute renal failure induced by topical ketoprofen. BMJ. 2000; 320(7227): 93.

69. Kikuchi $H$, Aoyagi M, Nagahama K, Yajima $Y$, Yamamura Co, Arai Y, Hirasawa S, Aki S, Inaba N, Tanaka H, Tamura T. Case Report: Nephrotic-range Proteinuria and Interstitial Nephritis Associated with the Use of a Topical Loxoprofen Patch. Intern Med. 2014; 53(11): 1131-1135.

70. Lucas GNC, Leitão ACC, Alencar RL, Xavier RMF, Daher EF, Silva Junior GBD. Pathophysiological aspects of nephropathy caused by non-steroidal anti-inflammatory drugs. J Bras Nefrol. 2019; 41(1): 124-130.

71. Jung JH, Kang KP, Kim W, Park SK, Lee S. Nonsteroidal antiinflammatory drug induced acute granulomatous interstitial nephritis. BMC Res Notes. 2015; 8:793.

72. Clive DM, StoffJS. Renal syndromes associated with nonsteroidal antiinflammatory drugs. N EnglJ Med. 1984; 310(9): 563-572.

73. Mohammed EP, Stevens JM. Recurrence of Arthrotecassociated nephrotic syndrome with re-challenge. Clin Nephrol. 2000; 53(6): 483-485.

74. Ejaz P, Bhojani K, Joshi VR. NSAIDs and Kidney. JAPI. 2004; 52: 632-640.

75. Nawaz FA, Larsen CP, Troxell ML. Membranous Nephropathy and Nonsteroidal Anti-inflammatory Agents. AJKD. Kidney Biopsy Teaching Case. 2013; 62(5): 1012-1017.

76. Feinfeld DA, Olesnicky L, Pirani CL, Appel GB. Nephrotic syndrome associated with use of the nonsteroidal anti-inflammatory drugs. Case report and review of the literature. Nephron. 1984; 37(3): 174-179.

77. Harirforoosh S, Asghar W, Jamali F. Adverse effects of nonsteroidal antiinflammatory drugs: an update of gastrointestinal, cardiovascular and renal complications. J Pharm Pharm Sci. 2013; 16(5): 821-847. 